\title{
Changing Geers: Engineering Instructor Perspectives on Education
}

\author{
Andrew Roncin, P.Eng. \\ Instructor, Electrical and Electronic Engineering Technology \\ Red River College \\ aroncin@rrc.mb.ca
}

\begin{abstract}
This paper is based on the qualitative research work done on instructor perspectives about teaching engineering. The purpose of which is to better understand the attitudes and motivations of instructor's so that when changes are recommended to accommodate CEAB requirements they are both appropriate and meaningful.

The paper briefly highlights the context and methodology of the research. But of interest to engineers and educators are the following three findings.

1. The diversity of answers in interpreting what a professional engineer is.

2. The different ways in which we connect theory and application in our classrooms.

3. How instructor expectations change along with student abilities.

These findings are examined in the context of bloom's revised taxonomy. To consider how the knowledge, cognitive are supported in engineering. From this, recommendations about using open ended (engineering) problems to develop student's confidence and abilities are considered.
\end{abstract}

\section{Introduction}

This paper is based on the qualitative research work done on the attitudes and perceptions of engineering instructors on education in Canada. The impetus being, engineering education around the world is in a real period of change.[1][2][3][4] And if in order to help engineering educators, one must understand both attitudes of people involved and the reasons for embracing change. [5]

To understand the challenges facing engineering education, one needs to understand how it is unique, [1][6] and what is happening within the engineering profession.

Engineering is unique from other disciplines in that its core focus is on giving students a general knowledge from which to tackle problems they have never seen before. Engineering instructors need to instil in students the confidence to take on new challenges and stick with them despite the problems.

Engineering is also unique from math and science because the problems do not have a single solution. At best, the solutions are a compromise between conflicting constraints and the needs of the user. When we consider math and science, we think about problems that ultimately have one solution. They are taught in a manner that student and teacher get the same answer. In engineering, getting the same answer means you have not done the work. In engineering design problems, compromise and constraints are at the heart of everything we do.

In 2008, the Canadian Engineering Accreditation Board fundamentally changed the way Engineering programs are accredited. By 2014, engineering schools are expected move from a prescriptive engineering science model, to an outcome based model which highlights design, teamwork, communication, and engineering science.[5] In doing so, they acknowledged a shift within the profession and formalized that engineering is about teamwork.

So the questions I wanted to ask were simple: What are instructors trying to achieve in their classroom and how do they do it?

\section{Methodology:}

During this research project I conducted four - one hour interviews with engineering faculty in Canada. The participants were randomly selected based on availability and a minimum of three years of teaching experience. Each participant (Alpha, Beta, Gamma, Delta) was asked five basic questions paraphrased below.

1. What level of students do you teach?

2. What background knowledge, skills and attitudes should they have?

3. What is your purpose in the classroom?

4. How do you do that?

5. If the level were to change, how would that affect your teaching 


\section{Key Findings:}

Through discussions with these four participants, three common themes became apparent. They each focused on creating professional engineers. Each sought to bring real world practice into the classroom. And each commented on how both student and instructor behaviour changed throughout the program.

\section{Creating Professional Engineers:}

Firstly, each professor was deeply committed to helping students become professional engineers. In their own way, each one stated

"My duty is to produce future engineers... If I don't teach them...how to think outside problems then, then it's a failure to me. That's why it's important to me." (Alpha)

Each professor focused on teaching their students to act and think like an engineer. Two of the four stressed developing the students as professionals, while the other two focused on the engineering career after graduation. The interesting part of this finding however is that each participant had a different vision of what a professional engineer did and the skills they needed to be successful (Table 1).

Table 1. Participant core messages

\begin{tabular}{|l|l|l|}
\hline Participant & Core message & Engineers are \\
\hline Alpha & $\begin{array}{l}\text { Connect theory } \\
\text { and practice }\end{array}$ & $\begin{array}{l}\text { Real world } \\
\text { problem solvers }\end{array}$ \\
\hline Beta & $\begin{array}{l}\text { Learn for more } \\
\text { than just a grade }\end{array}$ & $\begin{array}{l}\text { Communicators } \\
\text { and leaders }\end{array}$ \\
\hline Gamma & $\begin{array}{l}\text { Serve society } \\
\text { and yourself }\end{array}$ & $\begin{array}{l}\text { Planners and } \\
\text { managers }\end{array}$ \\
\hline Delta & $\begin{array}{l}\text { Find what you } \\
\text { love to do }\end{array}$ & $\begin{array}{l}\text { Technical } \\
\text { experts }\end{array}$ \\
\hline
\end{tabular}

\section{Connecting Theory and practice}

Secondly, as an aspect of teaching students to think like an engineer, each professor tried to connect the theory they were learning with real world professional practice. In the case of Alpha, the lab was used to build observation skills, and the data used as a focal point for discussion within the course.

"We do that in the lab first. Then we ended up coming to the classroom with it... I normally actually use a lecture period actually, [to ask students]. What strikes you. What did you observe... can you actually describe... like the failure process"(Alpha)

Beta and Gamma both featured projects and real world data in their classes.
"If you have a design project, you have to be willing to work in groups. You have to be willing, to ah, behave like a junior engineer" (Beta)

While Delta, used anecdotes to help students understand the context and problems of engineering practice.

"So I try very much too, to tell them, I mean to give them stories about good engineers, about this guy I was telling you about from $C N$ about how good engineers are supposed to be and how it is very a good career." (Delta)

In their own way, each instructor featured professional practice and the application of theory heavily in their course.

\section{Changing behaviour}

Thirdly, each instructor commented on how the students became "more self driven...more settled, and more curious" (Delta). They knew how to play the game and what was expected of them (Beta). That they started to perceive themselves as engineers and behave more like professionals. What they noticed was the students becoming more interested, engaged, and responsible for their learning. What they noticed was the students taking ownership of the experience.

As Delta brought forward, the students have to be "self critics", they have to take ownership of their work. Know if the quality was good enough. To move beyond the grade.

"I say if I mark you A+, what's an A+. And one say, 90\%. I said good. Yeah, it sounds good. Now, you have to go on a holiday, or your flying to visit your airport, And the air Canada person tells you this plane is $90 \%$ safe... 90\%. Would you go on the plane or not?" (Delta)

Most don't raise their hand

"Because $90 \%$ is good for your exam, because you're exam doesn't impact anything yet." (Delta)

\section{In the context of educational theory}

Considering these three trends in light of matrix form of Bloom's Revised Taxonomy [7], we see that the whole gambit of knowledge and cognition is covered linearly throughout the program. Engineering instructors move from teaching factual and procedural knowledge (engineering science) in years one and two, to building conceptual knowledge (engineering application) in years three and four (Table 3). Finally in the capstone or thesis course, students are suppose to be grounded enough, that they can move easily into metacognitive knowledge - knowing how to solve their own problems and understand the limits of their knowledge. 
Table 3. Development of the knowledge and cognitive domains.

\begin{tabular}{|c|c|c|}
\hline & Knowledge Dimension & Cognitive Dimension \\
\hline Year 1 & $\begin{aligned} & \text { Factual knowledge } \\
&- \text { theoretical } \\
&- \text { single answer problems }\end{aligned}$ & $\begin{aligned} \text { Remembering } \\
-\quad \text { Recognizing } \\
-\quad \text { Recalling }\end{aligned}$ \\
\hline Year 2 & $\begin{array}{c}\text { Factual and procedural } \\
-\quad \text { Discipline specific }\end{array}$ & \begin{aligned} \multicolumn{2}{l}{ Remembering } \\
$-\quad$ Recognizing \\
$-\quad$ Recalling \end{aligned} \\
\hline Year 3 & $\begin{array}{l}\text { Conceptual and procedural } \\
-\quad \text { Learning about constraint based } \\
\text { engineering } \\
\text { - } \quad \text { Learning about design procedures }\end{array}$ & $\begin{array}{cl}\text { Understanding and applying } \\
\text { - } & \text { interpreting, } \\
- & \text { classifying } \\
\text { - } & \text { comparing } \\
\text { - } & \text { Implementing }\end{array}$ \\
\hline Year 4 & $\begin{array}{l}\text { Metacognitive } \\
\text { - } \quad \text { Understanding how integrate knowledge } \\
\text { and concepts to create new solutions }\end{array}$ & $\begin{array}{cl}\text { Evaluating and creating } \\
\text { - } & \text { Planning, } \\
\text { - } & \text { Generating } \\
\text { - } & \text { Producing } \\
\text { - } & \text { Checking } \\
\text { - } & \text { Critiquing }\end{array}$ \\
\hline
\end{tabular}

In the context of engineering one discovers real problems with the terms analyze, evaluate, and create. Quite simply, the whole education process is geared to these three terms. So at what level, do we accept a student's competence? Is it just solving problems in a textbook? Or does it have a deeper, real world meaning. Are we meaning: the lights turn on? Planes stay in the air? Roads stay flat? From the standpoint of engineering, planning, producing, and checking are all fundamental and deep processes. Each of them is substantially required in creating solutions that work despite the environment around them. From the standpoint of creating systems that work, "solving" textbook problems is a procedural ability. Applying that knowledge in a new context requires much deeper knowledge and cognition. In this context, analyze, evaluate, and create have much deeper meaning. And accepting a lesser definition devalues the work involved.

Although problem solving is the mantra of engineering. Students do not have the theoretical background, the knowledge base to solve real world problems until late in the program (Table 2). The information base required leaves students facing a tirade of information filled lectures. It is only in later years, that the students are challenged with complex projects, and real world situations. Unfortunately, the point at which students can do this on their own does

Table 2: Bloom's Revised Taxonomy

\begin{tabular}{|c|c|c|c|c|c|c|c|}
\hline $\begin{array}{l}\text { Knowledge } \\
\text { Dimension }\end{array}$ & & Remember & Understand & Apply & Analyze & Eva & Cre \\
\hline $\begin{array}{l}\text { Factual } \\
\text { Knowledge }\end{array}$ & $\begin{array}{l}\text { Terminology } \\
\text { Facts and Figures }\end{array}$ & \multirow{3}{*}{\multicolumn{2}{|c|}{$\begin{array}{c}\text { Introductory } \\
\text { Theory }\end{array}$}} & & & & \\
\hline Conceptual & Interrelationships & & & \multirow{2}{*}{\multicolumn{3}{|c|}{ Engineering Science }} & \multirow{3}{*}{$\begin{array}{l}\text { Design } \\
\text { Courses }\end{array}$} \\
\hline $\begin{array}{l}\text { Procedural } \\
\text { Knowledge }\end{array}$ & Methodology and & & & & & & \\
\hline $\begin{array}{l}\text { Metacognitive } \\
\text { Knowledge }\end{array}$ & $\begin{array}{l}\text { Awareness of } \\
\text { your own patterns }\end{array}$ & & & \multicolumn{3}{|c|}{ Capstone/Thesis } & \\
\hline
\end{tabular}


not come until fourth year or after graduation.

"[In] the fourth year course...they are beyond the fact that you have base knowledge, and now have, would like to have them have some applied knowledge. Some design knowledge, some... problem solving in real cases." (Beta)

By the same token, students are treated differently as they progress through the program. In second and third year, the program focused heavily on disaggregate pieces of knowledge. Students were offered a smorgasbord of courses to give them a taste of subjects across the discipline (Delta). In third and fourth year, the knowledge, the theory from these courses is brought together, forming an aggregate from which they can do design (Gamma).

"We tend to like be very theoretical for the students. In the physicality's of engineering. But later we can give them [projects]. And [apply] the aggregate knowledge from different courses towards this theory. So in the first place we are doing some kind of disaggregation ok. These courses just concentrating on this area, and other courses area are concentrating on different area. But later if you have already gone through it, you can have some kind of aggregation of all this knowledge to be applied and more go to the physical." (Gamma)

\section{Considerations for education}

\subsection{The role of open ended problems.}

"Engineering students should only do the even numbered problems." [8]

Often in education, we are guilty of teaching students to look for one right answer. A student is right, a student is competent, when they can reproduce the same answer as the instructor. The challenge is, that doing so does not build the students ability to think creatively about problems. To understand what they know, and when faced with a problem, to adapt and overcome. By teaching students to focus on the right answer, we leave them handicapped when faced with the unknown. They freeze.

"[A]ll I have is what the client gives me. You make assumptions. And many students freeze. They freeze because there is twenty unknowns and two known's. And they have to make many assumptions." (Beta)

Unfortunately real world problems are complex and filled with unknowns. Often data is incomplete, people's opinions come into play, and we have to make assumptions. We have to find a way to solve problems that work in spite of factors we cannot control.

Using engineering problems, design problems, in our classrooms encourages students to use their knowledge, their creativity, and their passion. It teaches them to tackle problems based on what they know, rather than freezing because the problem is too big or too undefined.

Imagine if our students left high school confident, self assured, and able to work independently. Using open ended problems, teach them to think about what is going on. To integrate their knowledge across disciplines and across teams.

Giving students open ended problems lets them build confidence.

\subsection{Helping your students be problem solvers.}

In the worlds of Billy Koen, "Engineering is problem-solving, goal-directed and needs-fulfillment activity."[9] or as more simply captured by Henry Petroski, in the title of his first book, "To engineer is human”. Regardless of profession, we are all faced with engineering problems. Problems that require us to think, set goals and address our needs. By using open ended problems, by teaching students to come up with unique solutions, you are helping them be problem solvers. You are helping them be engineers.

So take time to teach students to understand their knowledge - to reframe it - to apply it in a new context. Challenge your students to create solutions to things you don't know the answer to. Let them experience the satisfaction of understanding a problem and creating a solution that satisfies their needs. The confidence they build will be amazing.

\section{Conclusion}

The challenge facing engineering education in Canada today is enhancing the curriculum to incorporate teamwork, communication, and life-long learning into our student's skill set. With this in mind, this paper looked at where we are right now. How is engineering education unique? And, what attitudes and skills do we teach?

Comfortingly, the results show instructors committed to the success of engineering, and the success of their students. All of the instructors were truly focused on creating professional engineers. Even though the image and skills of what that meant varied. Each wanted to bring real world practice and problem solving into the classroom. They believed students needed to be able to take fundamental theories and transpose them to new situations and problems. And finally, each felt the students became more engaged, focused, and involved as the program moved from theory into practice. 


\section{References}

[1] K. J. B. Anderson, S. S. Courter, T. NathansKelly, C. Nicometo, and T. McGlamery,

"Understanding the current work and values of professional engineers: Implications for engineering education," in Proceedings of the American Society of Engineering Education, Austin, TX, 2009.

[2] The Canadian Academy of Engineering, "Task Force on the Future of Engineering: A Framework for Discussion," Dec. 2005. [Online]. http://www.acad-enggen.ca/nouveau/caerptmdf62.pdf

[3] National Academy of Engineering,, The Engineer of 2020: VISIONS OF ENGINEERING IN THE NEW CENTURY. Washington, DC: National Academies Press, 2004, http://www.nap.edu.

[4] The Royal Academy of Engineering, "Educating Engineers for the 21st Century: The Industry View," 2006.

[5] Canadian Engineering Accreditation Board, "Accreditation Criteria and Procedures," Canadian Council of Professional Engineer, 2008.

[6] E. Godfrey and L. Parker, "Mapping the Cultural Landscopen in Engineering Education," Journal of Engineering Education, vol. 99, no. 1, pp. 522, Jan. 2010.

[7] D. R. Krathwohl, "A Revision of Bloom's Taxonomy: An Overview," Thoery Into Practice, pp. 212-218, 2002, http://www.unco.edu/cetl/sir/stating_outcome/do cuments/Krathwohl.pdf (May 6, 2011).

[8] M. Britton, [private interview]. March 2010.

[9] B. V. Koen, Definition of the Engineering Method. Washington, D.C.: American Society for Engineering Education, 1985. 